\title{
https://doi.org/10.48009/1_iis_2005_127-133 \\ SURVEY OF STUDENT USAGE OF DIGITAL TECHNOLOGY: TEACHING IMPLICATIONS
}

\author{
Susan Switzer, Central Michigan University, susan.switzer@cmich.edu \\ Nancy Csapo, Central Michigan University, nancy.csapo@cmich.edu
}

\begin{abstract}
The increase of digital technologies has led to the "digital age." In 2000, just over 33 percent of U.S. college students owned cell phones; as of the fall 2004, nearly 90 percent owned cell phones [5]. The most popular gadgets today in addition to cell phones include iPods, tablet PCs, and personal digital assistants (PDA). The huge popularity of cell phones among students has caused some educational institutions to give out hand-held devices to their students in hopes of piggybacking on the success of this phenomenon. Duke University's high profile iPod program is a perfect example of one university's effort to incorporate technology into learning and has received both positive and negative publicity. There are many capabilities that digital technologies have already brought to the classroom. But according to some, computing and communication technology has been implemented rather slowly into our schools for a variety of reasons [3]. But with the many affordable digital technologies available today, will this change? With the growth of so many handheld technologies, are there "new" benefits that educators need to be utilizing? Can we utilize these technologies to expand learning opportunities or as a learning tool in the classroom? Undergraduate students were surveyed to determine what digital technologies they use most to aid in determining what digital technologies could/should be taught and/or utilized in the business education and information systems curricula. In addition, identifying what resources are available, if any, to guide or direct the use of digital technologies in the classroom and/or curriculum will be addressed.
\end{abstract}

Keywords: digital tools, handheld devices, handheld technology, digital technologies, PDA, digital technologies resources, communication technology

\section{INTRODUCTION}

The increase of digital technologies has led to the "digital age." In 2000, just over 33 percent of U.S. college students owned cell phones; as of the fall 2004, nearly 90 percent owned cell phones [5]. The super phone of today gives one all the features of a PDA (including a digital camera) with the addition of messaging and Internet communications [4]. The most popular gadgets today in addition to cell phones include iPods, tablet PCs, and personal digital assistants (PDA). Digital technologies have already brought many capabilities to the classroom. But according to some, computing and communication technology has been implemented rather slowly into our schools for a variety of reasons [3]. According to Hardin and Ziebarth, universities need to become leaders in applying technology to education for learning and collaboration [3]. With the growth of so many low cost, handheld technologies, are there "new" benefits that educators need to be utilizing? Can we utilize these technologies to expand learning opportunities or as learning tools in the classroom? 
College students have an insatiable appetite for information [2]. The huge popularity of cell phones among students has caused some educational institutions to give out handheld devices to their students in hopes of piggybacking on the success of this phenomenon [1]. "The use of technology can create real efficiencies in [students'] social and academic lives, and for today's college students, technology is not so much a luxury, but a necessity that's become seamlessly integrated into their everyday environment" [2]. Duke University's high profile iPod program is an example of one university's effort to incorporate students' attraction to technology into learning; the program has received both positive and negative publicity.

\section{PURPOSE OF THE STUDY}

The purpose of this study was to determine the following: (1) what digital technologies do undergraduate business students use most; (2) what digital technologies should be taught and/or incorporated in the business education and information systems curricula; and (3) what resources are available to guide or direct the use of digital technologies in the classroom and curriculum?

\section{REVIEW OF RELATED LITERATURE}

Technology is affecting education in revolutionary ways and the momentum toward these changes is irreversible [3]. The use of handheld technologies in schools has already seen some success at the K-12 level. The use of handheld technologies such as Palm's Palm Pilots and Hewlett Packard's Jornadas has been tested in several high schools across the Southeast to determine if providing these technologies to every student would be beneficial [10]. One of the major advantages of these handheld computing devices is their potential to overcome the problem of access to technology and "to creating equity of use in the classroom" [10].

Due to lower costs, increased functionality, and the availability of new software designed specifically for education, K-12 schools are beginning to take a serious look at handheld computing for teaching and learning, administrative tasks, and communication and collaboration. In fact, the potential for using handhelds in education is almost limitless [10].

The educational advantages of handheld technologies for school are numerous and include cost (typical cost for students is \$100-\$300), mobility, wireless, size/portability, ownership (students take care of "cool" devices so they don't lose the privilege of using them), access (equal access for all students), collaboration and sharing (beaming has been found to motivate students to work together and share information), and simplicity/ease of use (teachers do not have to spend a lot of time teaching students how to use them) [10]. Potential concerns for the educational use of handheld technologies also exist, such as compatibility issues, cheating potential, distractions (such as game playing or Web surfing), effectiveness/research (the affect on student achievement has not been adequately measured as of now), infrastructure (peripherals, hardware, and software requirements add to the expense), ownership, professional development (resource availability for training students and staff to fully utilize the technology), replacement issues, safety (such as eyestrain and carpal tunnel), screen readability, screen size, security, and tech support [10]. 
One of the most publicized efforts of utilizing digital devices at the post-secondary level is Duke's iPod program. Duke's 1,600 freshmen received a brand-new iPod and microphone attachment for "educational purposes" [1]. The $\$ 500,000$ iPod program is "an attempt to do something bold to get attention, especially from professors" [1]. Duke's provost, Peter Lange, explains how Duke has been behind in technology, saying "the diffusion of technology among faculty, if left to its own devices, happens at a slow pace" [1]. Other institutions, in most every case, are getting some kind of marketing boost in giving out hand-held devices whether these freebies are as inexpensive as key drives or as expensive as tablet PCs [1].

\section{METHODOLOGY}

This study was conducted at a Division I comprehensive public university in the Midwest with undergraduate enrollment of 17,949 for the 2004-05 academic year. Students enrolled in two College of Business Administration business communication courses (a 300-level course, Business Communication, and a 100-level course, Essential Business Communication Skills) were asked to participate in the study. A short, on-line questionnaire was made available to these students for a two-week period during the spring semester 2005. The questionnaire was designed to determine what digital technologies students use most, what motivates them to purchase these devices, and whether the use of such devices in their classes would be of interest to them or not. The findings, conclusions, and recommendations will be applicable to administrators, faculty, and students.

A total of 647 students were enrolled in the two business communication courses included in the study (352 students in the 300-level course; 295 students in the 100-level course). A total of 493 surveys were completed for a response rate of 76.2 percent. Of the 493 respondents, 210 (42.6 percent) were female and 282 (57.2 percent) were male. As shown in Table 1, the vast majority of student respondents fell into two age groups: 256 (51.9 percent) were 18-20 years of age and 201 (40.8 percent) were 21-23 years old.

Table 1. Age of Respondents

Age Range

18-20 years old

21-23 years old

24-28 years old

29-35 years old

$36+$ years old

No response

Total
Number Responses

$\begin{array}{cc}256 & 51.9 \% \\ 201 & 40.8 \% \\ 22 & 4.5 \% \\ 5 & 1.0 \% \\ 3 & .6 \% \\ 6 & 1.2 \% \\ 493 & 100.0 \%\end{array}$

Table 2 shows the class standing of the respondents with the largest number of students (211 or 42.8 percent) being juniors, followed by 171 (34.7 percent) freshmen, and 103 (20.9 percent) seniors. 
Table 2. Class Standing of Respondents

\begin{tabular}{lcc} 
Class Standing & Number Responses & Percent of Responses \\
\hline Freshman & 171 & $34.7 \%$ \\
Sophomore & 4 & $.8 \%$ \\
Junior & 211 & $42.8 \%$ \\
Senior & 103 & $20.9 \%$ \\
Other & 4 & $.8 \%$ \\
Total & 493 & $100.0 \%$
\end{tabular}

FINDINGS

Students were asked to identify how much they use specific digital devices based on a scale of $0-4$ with " 0 " = never/do not own; "1" = rarely; " 2 " = occasionally; " 3 " = regularly; and " 4 " = extensively. Table 3 shows the types of digital devices used most by students and to what extent. The vast majority of students (81.9 percent or 404) do not own an iPod and another 45.8 percent or 226 do not own any other type of digital music device (non-iPod). However, 352 students do own some type of digital music player with varying levels of usage, of which 64 use extensively.

Only one digital device, a cell phone with basic calling features, was used "extensively" by the largest percent of students (61.9 percent or 305). The second most frequently used digital device was a cell phone with two-way/walkie-talkie with 29.2 percent or 144 students indicating they used this device "extensively" while 52.1 percent or 257 students never/do not own a device with this feature. Of all the digital devices, the cell phone greatly exceeded usage rates when compared to any other device (digital music player, tablet PC, PDA, and Blackberry). The most popular cell phone features were (in order of combined extent of usage from rarely to extensively): basic calling features, 483 (98.0 percent); calendar/date book, 334 (68.7 percent); with Internet, 320 (65.9 percent); text messaging, 318 (64.5 percent); digital camera, 271 (55.0 percent); two-way/walkie-talkie, 236 (47.9 percent); video camera, 77 (15.6 percent); and GPS, 52 (10.5 percent).

Table 3. Usage of Digital Devices

\begin{tabular}{|c|c|c|c|c|c|c|c|c|c|c|}
\hline \multirow{2}{*}{$\begin{array}{l}\text { Usage Rating } \rightarrow \\
\text { Digital Device } \\
\end{array}$} & \multicolumn{2}{|c|}{$\begin{array}{c}\text { Never/ } \\
\text { Do not own }\end{array}$} & \multicolumn{2}{|c|}{ Rarely } & \multicolumn{2}{|c|}{ Occasionally } & \multicolumn{2}{|c|}{ Regularly } & \multicolumn{2}{|c|}{ Extensively } \\
\hline & $\#$ & $\%$ & $\#$ & $\%$ & $\#$ & $\%$ & $\#$ & $\%$ & $\#$ & $\%$ \\
\hline iPod & 404 & 81.9 & 24 & 4.9 & 12 & 2.4 & 31 & 6.3 & 21 & 4.3 \\
\hline $\begin{array}{l}\text { Digital music } \\
\text { player (non-iPod) } \\
\text { Cell phone - basic }\end{array}$ & 226 & 45.8 & 62 & 12.6 & 76 & 15.4 & 83 & 16.8 & 43 & 8.7 \\
\hline $\begin{array}{l}\text { calling features } \\
\text { Cell phone - }\end{array}$ & 10 & 2.0 & 4 & .8 & 21 & 4.3 & 153 & 31.0 & 305 & 61.9 \\
\hline $\begin{array}{l}\text { digital camera } \\
\text { Cell phone - }\end{array}$ & 218 & 44.2 & 59 & 12.0 & 111 & 22.5 & 74 & 15.0 & 27 & 5.5 \\
\hline $\begin{array}{l}\text { text messaging } \\
\text { Cell phone - }\end{array}$ & 172 & 34.9 & 111 & 22.5 & 94 & 19.1 & 69 & 14.0 & 44 & 8.9 \\
\hline calendar/date book & 157 & 31.8 & 134 & 27.2 & 78 & 15.8 & 73 & 14.8 & 49 & 9.9 \\
\hline
\end{tabular}


Cell phone -

with Internet

Cell phone -

two-way/w-talki

Cell phone -

video camera

Cell phone - GPS

Tablet PC

PDA

Blackberry

Other

$\begin{array}{cccccccccc}168 & 34.1 & 83 & 16.8 & 47 & 9.5 & 69 & 14.0 & 121 & 24.5 \\ 257 & 52.1 & 31 & 6.3 & 22 & 4.5 & 39 & 7.9 & 144 & 29.2 \\ & & & & & & & & & \\ 342 & 69.4 & 0 & 0.0 & 56 & 11.4 & 9 & 1.8 & 12 & 2.4 \\ 378 & 76.7 & 0 & 0.0 & 39 & 7.9 & 10 & 2.0 & 3 & .6 \\ 364 & 73.8 & 28 & 5.7 & 15 & 3.0 & 28 & 5.7 & 49 & 9.9 \\ 406 & 82.4 & 32 & 6.5 & 23 & 4.7 & 18 & 3.7 & 12 & 2.4 \\ 469 & 95.1 & 13 & 2.6 & 3 & .6 & 2 & .4 & 0 & 0.0 \\ 0 & 0.0 & 1 & .2 & 1 & .2 & 1 & .2 & 9 & 1.8\end{array}$

The extent of usage by students for the remaining digital devices when combining all usage levels from rarely to extensively were as follows: tablet PC, 120 (24.3 percent); PDA, 85 (17.2 percent); Blackberry, 18 (3.7 percent); and "other" devices, 12 (2.4 percent). "Other" consisted of laptop (7 responses), desktop computer (4 responses), flash drive and GameBoy (1 response).

Table 4 identifies what factors motivated students most in purchasing specific digital devices.

The number one motivating factor for students in purchasing a cell phone was convenience with 40.6 percent of students selecting this factor. The second motivating factor for students in purchasing a cell phone was features (17.4 percent), followed by price (15.2 percent). The most motivating factor in purchasing an iPod was features, while the most motivating factor in purchasing a non-iPod digital music player was convenience.

The motivating factor identified most across all devices by students was features, 404 (13.6 percent); followed by convenience, 369 (12.4 percent); price, 291 (9.8 percent); required for school/work, 80 (2.7 percent); and lastly, support/service/warranty, 61 (2.1 percent).

Only 80 students (2.7 percent overall) indicated the motivating factor for purchasing a digital device was because it was required for school or work. The device most purchased for this factor was a tablet PC with 38 students (7.7 percent) identifying this factor.

Table 4. Motivating Factors for Purchasing Digital Devices

\begin{tabular}{|c|c|c|c|c|c|c|c|c|c|c|c|c|}
\hline \multirow{2}{*}{$\begin{array}{l}\text { Factor } \rightarrow \\
\text { Device }\end{array}$} & \multicolumn{2}{|c|}{$\begin{array}{c}\text { Not } \\
\text { Applicable }\end{array}$} & \multicolumn{2}{|c|}{ Price } & \multicolumn{2}{|c|}{ Features } & \multicolumn{2}{|c|}{ Convenience } & \multicolumn{2}{|c|}{$\begin{array}{c}\text { Support/ } \\
\text { Service/ } \\
\text { Warranty }\end{array}$} & \multicolumn{2}{|c|}{$\begin{array}{c}\text { Required } \\
\text { for school } \\
\text { or work }\end{array}$} \\
\hline & \# & $\%$ & \# & $\%$ & \# & $\%$ & \# & $\%$ & $\#$ & $\%$ & \# & $\%$ \\
\hline iPod & 316 & 64.1 & 49 & 9.9 & 53 & 10.8 & 48 & 9.7 & 1 & .2 & 4 & .8 \\
\hline Non-1 & 219 & 44.4 & 73 & 14.8 & 86 & 17.4 & 99 & 20 & 1 & .2 & 3 & .6 \\
\hline Cell & 10 & 2.0 & 75 & 15.2 & 151 & 30.6 & 200 & 40 & 36 & 7.3 & 14 & 2.8 \\
\hline Tablet & 311 & 63.1 & 38 & 7.7 & 53 & 10.8 & 20 & 4.1 & 10 & 2.0 & 38 & 7.7 \\
\hline PDA & 355 & 72.0 & 30 & 6.1 & 45 & 9.1 & 21 & 4. & 7 & 1.4 & 12 & 2.4 \\
\hline Blackber & 407 & 82.6 & 26 & 5.3 & 16 & 3.2 & 5 & 1.0 & 6 & 1.2 & 9 & 1.8 \\
\hline *Total & 1,618 & 54.5 & 291 & 9.8 & 404 & 13.6 & 369 & 12.4 & 61 & 2.1 & 80 & 2.7 \\
\hline
\end{tabular}

*Based on six devices @ 493 responses each =2,968 possible responses 
Students were also asked if the required use of a digital device by a professor would cause them to select that class over another class where a digital device is not used. The majority of students (340 or 69 percent) responded "no" to this question, indicating that they would not give preference to taking a class that required the use of a digital device.

\section{DIGITAL TECHNOLOGY RESOURCES}

Research was also conducted to determine what resources are available to guide or direct the use of digital technologies in the classroom and the curriculum. Resources are widely available concerning incorporating technology into the curricula. For example, Seale reports on 170 ideas for integrating technology into planning and curriculum [6]. Sources for using specific digital devices are limited; however, generic methodologies can easily be adapted from device to device. One study at the University of Minnesota asked faculty what advice they would give a colleague who is considering using educational technology in his or her teaching. One faculty member responded by saying, "Just jump in and try it - the fear of trying is worse than the actual doing" [9].

Most resources and information on the educational uses for digital devices are specifically for PDAs and come from K-12 sources such as the SouthEast Initiatives Regional Technology in Education Consortium [10]. This consortium consists of a state-wide network of educators and is a program of the University of North Caroline at Chapel Hill School of Education. Their on-line publication, Newswire, contains information reporting the results from teachers, staff, and students of member schools who have undertaken pilot projects for the use of handhelds in the classroom. Included are recommendations and advice for others on successfully implementing the educational use of handheld technology along with specifics on advantages, disadvantages, considerations when buying, sample projects, and additional resources. Also included is a list of grant opportunities for educational technology.

Colleges and universities in particular can take advantage of the fact that tech companies want to establish brand loyalty early with college students and will donate or offer hardware and software at a reduced price to these institutions [8]. Institutions are providing a marketing boost in giving out handheld devices such as inexpensive key drives or more expensive items like table PCs [1]. Samford University in Alabama gave out free data-storage cards on key chains as an inexpensive way to offer students a technological tool [1].

\section{CONCLUSIONS AND RECOMMENDATIONS}

The findings of this study indicate the use of digital devices by current undergraduate business students at this institution do not own or use extensively a variety of digital devices. Rather, students use only one handheld device extensively: the cell phone with basic calling features, and the majority of students would not give preference to taking a class where a digital device is required. Students are motivated to purchase a cell phone primarily because of convenience. Students are motivated to purchase digital devices overall because of the features available and secondly, for convenience. Very few students purchased these devices because they are required equipment for school or work, indicating they purchased these devices primarily for personal use. 
Digital technologies should be taught and/or utilized in the business education and information systems curricula. The educational advantages for using handheld devices over full-size computers are impressive. Using handheld technologies in schools has enabled schools to provide equal access to technology for all students and has been shown to increase student motivation for learning while providing an effective tool for encouraging team work and information sharing among students. The trend in K-12 schools is indicating the success of using PDAs throughout the curriculum and at a variety of grade levels. Post-secondary institutions, like Duke University, may be correct in feeling they are lagging behind in the integration of these handheld technologies in their classrooms.

\section{REFERENCES}

1. Carlson, S. (September 2004). With This Enrollment, a Toy Surprise, The_Chronicle of Higher Education, http://chronicle.com, retrieved February 21, 2005.

2. College Students Tote $\$ 122$ Billion in Spending Power Back to Campus This Year, Harris Interactive, www.harrisinteractive.com/news, retrieved February 21, 2005.

3. Hardin, J. \& Ziebarth, J. (January, 2000). Digital Technology and its Impact on Education, The Future of Networking Technologies for Learning, www.ed.gov/Technology/Futures/ hardin.html, retrieved February 24, 2005.

4. Matthews, D. (2002) Here Come the Super Cell Phones, Young Money, www.youngmoney.com/technology, retrieved April 4, 2005.

5. Mobile Usage, IT Facts, www.itfacts.biz, retrieved April 4, 2005.

6. Seale, V. (June 2002). Integrating Technology into Planning and Curriculum, www.ael.org/rtec/ideas.htm, retrieved February 10, 2005.

7. Tablet PCs Find Home in Higher Ed, BizEd, (March/April 2005), 48-50.

8. Torabi, F. Hi-Tech Devices Move From Luxury to Necessity for College Students, Young Money, www.youngmoney.com/technology, retrieved April 4, 2005.

9. University of Minnesota, Faculty Technology Survey Executive Report, (November 2004). http://dmc.umn.edu/surveys/faculty/fsreport04.pdf, retrieved March 9, 2005.

10. Using Handheld Technologies in Schools, SEIRTEC NewsWire, (Fall 2002) 5(2), 1-34, www.unc.edu/learnnc/handhelds.pdf, retrieved March 4, 2005. 